\title{
Biogas Potential From Slaughterhouse Wastes at Ambient Temperatures in Lira Municipality of Northern Uganda
}

Chrish Kavuma ( $\sim$ kavumachris@gmail.com )

Busitema University

Isaac Ekwar

Busitema University

Resty Nabaterega

Busitema University

Joseph Ddumba Lwanyaga

Busitema University

Paul Sserumaga

Busitema University

Research

Keywords: slaughterhouses, punch, cow dung, wastewater, inoculum, biogas

Posted Date: October 6th, 2020

DOI: https://doi.org/10.21203/rs.3.rs-75434/v1

License: (9) This work is licensed under a Creative Commons Attribution 4.0 International License. Read Full License 


\title{
BIOGAS POTENTIAL FROM SLAUGHTERHOUSE WASTES AT AMBIENT TEMPERATURES IN LIRA MUNICIPALITY OF NORTHERN UGANDA
}

\author{
Chrish Kavuma $^{1 *}$, Isaac Ekwar ${ }^{2}$, Resty Nabaterega ${ }^{1}$, Joseph D. Lwanyaga $^{2}$, Paul Sserumaga ${ }^{3}$ \\ ${ }^{1}$ Department of Agricultural Mechanization and Irrigation, Busitema University, Tororo 236, Uganda \\ ${ }^{2}$ Department of Water Resources Engineering, Busitema University, Tororo 236, Uganda \\ ${ }^{3}$ Department of Chemical and Agro-processing, Engineering, Busitema University, Tororo 236, Uganda \\ ${ }^{*}$ Corresponding Author, Email: kavumachris@gmail.com, TEL: +256 782264023
}

\begin{abstract}
The generation of biodegradable solid waste and wastewaters is characteristic of all slaughterhouses including the Lira Municipality slaughterhouse (LMS) in northern Uganda. However, the LMS is not properly designed to handle and manage the ever-increasing biodegradable solid waste and wastewater. The wastes discharged from LMS, contain reasonable amounts of paunch, fat, grease, undigested food, diluted blood, suspended material, urine, loose meat and soluble protein. The lack of a properly designed slaughterhouse in Lira Municipality, needed to manage and handle the waste has resulted in the discharge of the waste into the environment, leading to pollution of water sources, outbreaks of diseases, and production of unfavorable odors. The objective of this study was to investigate the biogas potential of the LMS biodegradable solid waste and wastewaters at ambient temperatures. The waste was quantified based on Measurement at the point of generation method. Representative samples were characterized for biogas potential. Five treatments of the waste replicated three times were anaerobically digested in $1500 \mathrm{~mL}$ batch digesters with a working volume of $750 \mathrm{~mL}$. Treatment A contained only the inoculum and inoculum in the other treatments B, C, D, and E was approximately $20 \%$ of the volume of the substrate. Substrate: water ratio of $1: 1$, maintained $\mathrm{pH}$ of 6.0- 7.0 and retention time of 30 days were used for the study under ambient conditions. On average, 2,597 L, $40 \mathrm{~kg}$ and $502 \mathrm{~kg}$ of wastewater, cow dung and punch manure respectively were produced from LMS. The quantity and methane content of the biogas ranged from 1029.6 to $3512.7 \mathrm{ml} / \mathrm{gVS}$ and 40.6 to $50.4 \%$ respectively. Therefore, slaughterhouse wastes are potential sources of biogas production at ambient temperatures.
\end{abstract}

Keywords: slaughterhouses, punch, cow dung, wastewater, inoculum, biogas 


\section{Introduction}

According to [1], there is an increasing demand for meat in the world which has led to increased establishments of slaughterhouses. Within a series of processes, slaughterhouses generate vast amounts of different solid wastes and wastewaters [2]. Approximately, 20-50\% of the weight of the animal is not suitable for human consumption [3] thus a lot of by-products are produced such as; paunch, fat and, grease, undigested food, diluted blood, suspended material, urine, loose meat, soluble proteins, excrement among others.

However, many slaughterhouses in the developing countries are not designed to properly manage their wastes such as; the paunch, cow dung, and wastewater. For example, Lira Municipality slaughterhouse, located in Railways division, in Northern Uganda, is the only one in the municipality, operating beyond the designed capacity of 100 cows slaughtered instead of 60 daily. This slaughterhouse produces vast amounts of biodegradable wastes which end up in open places and nearby water bodies as there is no currently organized system for their disposal. These improperly managed wastes from the slaughterhouse pollute the environment, act as breeding places for disease-causing vectors and create bad odour. This makes the living conditions within the community and its outskirts unfavorable. However, these wastes can be converted into useful clean energy (biogas) and fertilizer inform of slurry through anaerobic digestion process since they are organic in nature. According to [4], biogas technology has helped some countries such as India and China in many ways including income generation, life-style improvements and cost saving. Moreover, the conversion of slaughterhouse wastes into clean energy has not been fully tapped in Uganda and it is against this background that this study was conducted. The objective of this study was to investigate the biogas potential from the slaughterhouse wastes at ambient temperatures in Lira district, Northern Uganda. 


\section{Methods and materials}

\subsection{Study area}

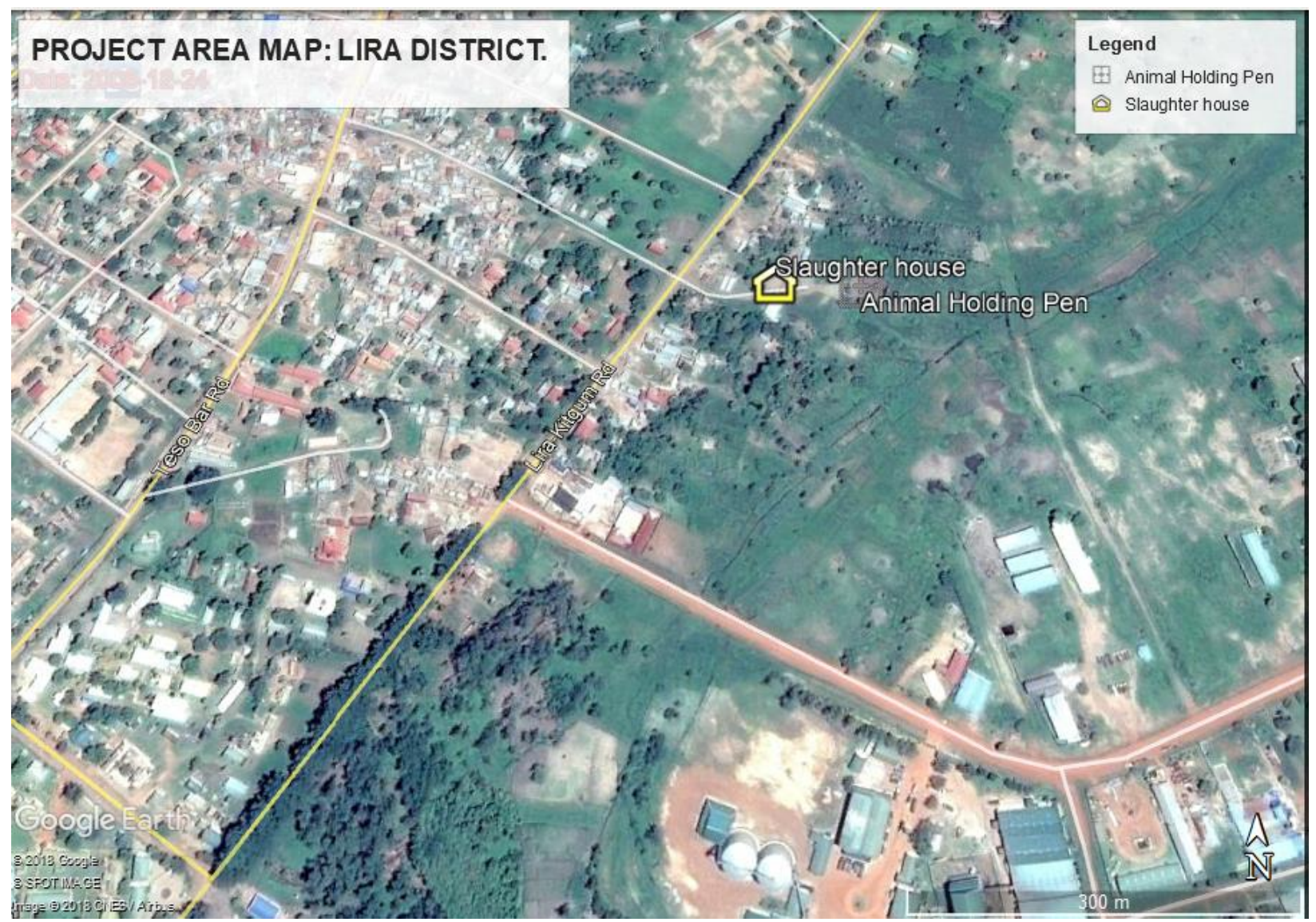

Figure 1: Map showing Lira slaughter house and Holding pen

The study to investigate the biogas potential from the slaughterhouse wastes at ambient temperatures was carried out from Lira Municipality (LM), Northern Uganda. Lira Municipality has four Divisions, 22 wards and 64 cells (Figure 1). It covers an area of 7,745 hectares and is surrounded by swamps. Lira Municipality has an altitude of $489678.50 \mathrm{~m}$ and longitude of $249418.12 \mathrm{~m}$ respectively.

\section{Collection and quantification of biodegradable waste generated from LM slaughterhouse}

The biodegradable waste generated from the slaughterhouse was quantified based on Measurement at the point of generation method [5]. Cow dung from the animal holding pen, paunch manure from the slaughter area and wastewater tapped from the outlet of the slaughterhouse were collected and measured using different pre-weighed calibrated buckets of 16 litre capacity and a digital 
weighing scale. The wastewater which contained diluted blood, fats, urine and pieces of meat trimming was then quantified for a period of ten (10) days.

\section{Sample preparation and characterization of the biodegradable slaughterhouse waste for biogas production}

The waste was cleaned by removing the non-biodegradable wastes such as the bones, plastic bags, metals among others and reduced in size by mashing into paste. Representative samples were then placed in clean plastic bottles and immediately analyzed on the laboratory scale for: total solids (TS), volatile solids (VS), fixed solids (FS), carbon/nitrogen ratio $(\mathrm{C} / \mathrm{N})$, and $\mathrm{pH}$ using standard methods [6]. The aluminum dishes that were used in the laboratory analyses were first ignited at $550^{\circ} \mathrm{C}$ for one hour in the furnace to remove any volatiles, cooled in the desiccator and weighed. The samples were heated at $103^{\circ} \mathrm{C}$ for 6 hours and at $550^{\circ} \mathrm{C}$ for 30 minutes to determine the total solids and volatile solids respectively. An electronic digital $\mathrm{pH}$ meter was used to determine the $\mathrm{pH}$ of the representative samples. The determination of waste organic carbon was based on the Walkley-Black chromic acid wet oxidation method, potassium dichromate as the oxidizing agent with other reagents of sulphuric acid and ferrous sulphate. The percentage and quantity of carbon was determined from Equations 1and 2, adopted:

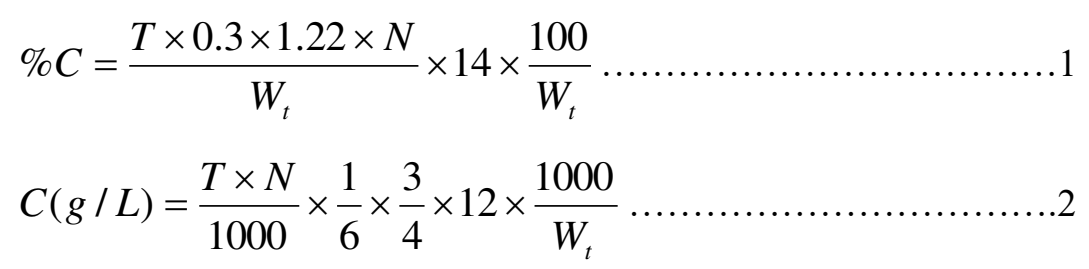

Where:

$\mathrm{N}=$ Normality of $\mathrm{K}_{2} \mathrm{Cr}_{2} \mathrm{O}_{7}$ solution

$\mathrm{T}=$ Volume of $\mathrm{FeSO}_{4}$ used in sample titration $(\mathrm{mL})$

$\mathrm{Wt}=$ Oven-dry sample weight $(\mathrm{g})$

The Kjeldahl method involving the three steps of digestion, distillation and titration was used to determine the nitrogen in the biodegradable waste. The reagents that were used included Potassium sulphate, concentrated sulphuric acid, sodium hydroxide, boric acid and $\mathrm{HCl}$ [7]. The percentage and quantity of Nitrogen was determined using Equation 3 and 4.

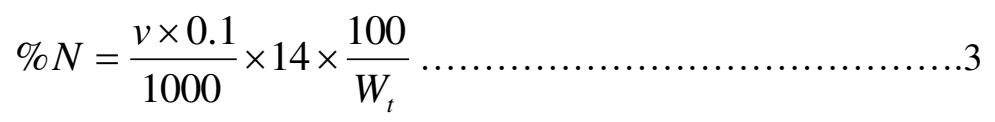


$N(g / L)=\frac{v \times 0.1}{1000} \times 14 \times \frac{1000}{5} \ldots \ldots \ldots \ldots \ldots \ldots \ldots \ldots \ldots \ldots \ldots$

Where:

$\mathrm{V}$ is volume of titrant in $\mathrm{ml}$ which is the volume HCL used

$\mathrm{W}_{\mathrm{t}}$ is Oven-dry sample weight $(\mathrm{g})$

Carbon nitrogen $(\mathrm{C} / \mathrm{N})$ ratio was then computed based on the results of the carbon and nitrogen. For reliability of the data and conclusions, three laboratory analyses were involved three replications.

\section{Biochemical Methane Potential (BMP) Test experimental setup}

Five treatments of the slaughterhouse waste (Table 1), replicated three times were anaerobically digested in $1500 \mathrm{~mL}$ batch digesters with a working volume of $750 \mathrm{~mL}$.

Table 1: Slaughterhouse waste treatments for the BMP tests

\begin{tabular}{lll}
\hline S/N & Treatments & Composition by mass (\%) \\
\hline 1 & A (control) & 100 inoculum \\
2 & B & 10 cow dung and 90 slaughterhouse wastewater \\
3 & C & 50 cow dung and 50 punch manure \\
4 & D & 75 punch manure and 25 slaughterhouse wastewater \\
5 & E & 10 cow dung, 70 punch manure and 20 slaughterhouse \\
& & wastewater \\
\hline
\end{tabular}

The inoculum that was used in the study was obtained from an already existing digester being fed with a mixture of food waste and cow dung as the substrates. Treatment A (control) contained only the inoculum and the inoculum in the other treatments B, C, D, and E was approximately $20 \%$ of the volume of the substrate. The substrate-to-water ratio that was used in the study was 1:1[8]. Zero Point eight grams $(0.8 \mathrm{~g})$ of Sodium Carbonate powder was added to all the batch digesters to maintain $\mathrm{pH}$ between 6.0- 7.0 which is within the $\mathrm{pH}$ range required for biogas production. The retention time used for the study was 30 days under ambient conditions (temperature between 25 and $\left.30^{\circ} \mathrm{C}\right)$.

The Biogas that was obtained was then collected by water displacement method. In order to prevent the dissolution of biogas in the water, acidified brine solution was prepared following the 
method suggested by [9]. Since the biogas was insoluble in this solution, a pressure was built-up that provided the driving force for displacement of the solution. Thus, the displaced brine solution was measured to represent the amount of biogas produced daily. The biogas produced from the digesters was collected by downward delivery of gas, achieved by filling the burettes with brine solution and inverting them in beakers containing same solution. The reactors were agitated twice a day to make the microorganisms more active during the digestion process for maximum biogas production.

After the 30 days retention time, the gases were left to collect in the digestion bottles where it was delivered to Green Heat for the different gas composition analyses. The percentage of the gases in the biogas were determined by connecting the gas with a cannula to the Geotech portable GA2000 gas analyzer through the inlet port which had an adjuster for connecting the flexible tube. Proportions of $\mathrm{CH}_{4}, \mathrm{CO}_{2}, \mathrm{~N}_{2}, \mathrm{H}_{2} \mathrm{~S}, \mathrm{CO}$ and $\mathrm{O}_{2}$ were determined and recorded. A one-way analysis of variance (ANOVA) in Genstat software was performed $(\mathrm{p} \leq 0.05)$ to verify any significant difference among the treatments.

\section{Results and discussion}

Quantification of biodegradable waste generated from LM slaughterhouse

On average, 2,597 L, $40 \mathrm{~kg}$ and $502 \mathrm{~kg}$ of wastewater, cow dung and punch manure respectively were produced from Lira Municipality slaughterhouse daily Table 2. Generally, more waste (wastewater, cow dung and punch manure) was produced on Sundays as compared to other days. This could be attributed to the fact that weekends people are on work leave so they travel upcountry homes where LM slaughter house is located to feast with dear ones (generally weekends are reunion days which call for more feasting of beef).

Table 2. Lira Municipality slaughterhouse waste production

\begin{tabular}{llll}
\hline Day & Wastewater $(\mathbf{L})$ & Cow dung (kg) & Punch manure (kg) \\
\hline Saturday & 2,153 & 34 & 302 \\
Sunday & 4,120 & 46 & 972 \\
Monday & 2,251 & 38 & 377 \\
Wednesday & 2,340 & 40 & 432 \\
Thursday & 2,470 & 41 & 476 \\
\hline
\end{tabular}




\begin{tabular}{llll}
\hline Friday & 2,441 & 39 & 461 \\
Saturday & 2,640 & 44 & 486 \\
Sunday & 3,220 & 47 & 658 \\
Monday & 2,100 & 36 & 428 \\
Tuesday & 2,235 & 38 & 432 \\
Average & $\mathbf{2 , 5 9 7}$ & $\mathbf{4 0}$ & $\mathbf{5 0 2}$ \\
\hline
\end{tabular}

\section{Characterization of the biodegradable slaughterhouse waste for biogas production}

The total solids, volatile solids and fixed solids ranged from 16 to 19,71 to 79 and 21 to 30 respectively (Table 3). The findings of this study are in line with the study results of Gebrekidan et al., [10] where the total solids and volatile solids of animal manure were found to vary between $16 \%$ to $20 \%$ and $80 \%$ respectively. The recommended value for slurry is between 8 percent and 12 percent. According to literature reports [10], the \%VS of animal waste are usually around 80 percent of the TS. The high proportion of VS in the manure substrate depicts that a large fraction of the substrate was biodegradable and could serve as an important feedstock for biogas production [11].

The $\mathrm{C} / \mathrm{N}$ ratio for this study ranged from 2.6 to 17.5 (Table 3). This was relatively lower than the recommended range for anaerobic digestion process of 20:1 to 30:1 [12]. Moreover, in a study conducted by [12], $\mathrm{C} / \mathrm{N}$ ratio of cow manure is about 16 to 25 . However, to achieve the objective of this study, the different slaughterhouse wastes were mixed in varying ratios to improve the $\mathrm{C} / \mathrm{N}$ ratio. The varying ratios may, therefore have been responsible for minimizing the liberation of nitrogen in form of ammonia. The $\mathrm{pH}$ of the substrate ranged from 6.8 to 6.9 as shown in (Table 3) which was within ideal range of 6.5 to 8.0 for anaerobic digestion.

Table 3: Average values from the characterization of the slaughterhouse waste

\begin{tabular}{llllll}
\hline Slaughterhouse & Total & Volatile & Fixed & C/N & pH \\
waste & solids & solids & solids & ratio & \\
& TS $(\%)$ & VS $(\%)$ & FS $(\%)$ & & \\
\hline Wastewater & 19 & 71 & 28 & 2.6 & 6.9 \\
Cow dung & 19 & 73 & 30 & 17.5 & 6.9 \\
Punch & 16 & 79 & 21 & 15.8 & 6.8 \\
\hline
\end{tabular}




\section{Biochemical Methane Potential (BMP) Test \\ Quantity of biogas}

All the digesters started gas production on the second day except for the inoculum (A) where gas production commenced on day one (Figure 2). The earlier start of gas production in inoculum (A) may have been attributed to the fact that the inoculum (A) already contained active microorganisms that were adapted to the reaction conditions in the digester thereby lowering the lag phase of the microbial growth curve.

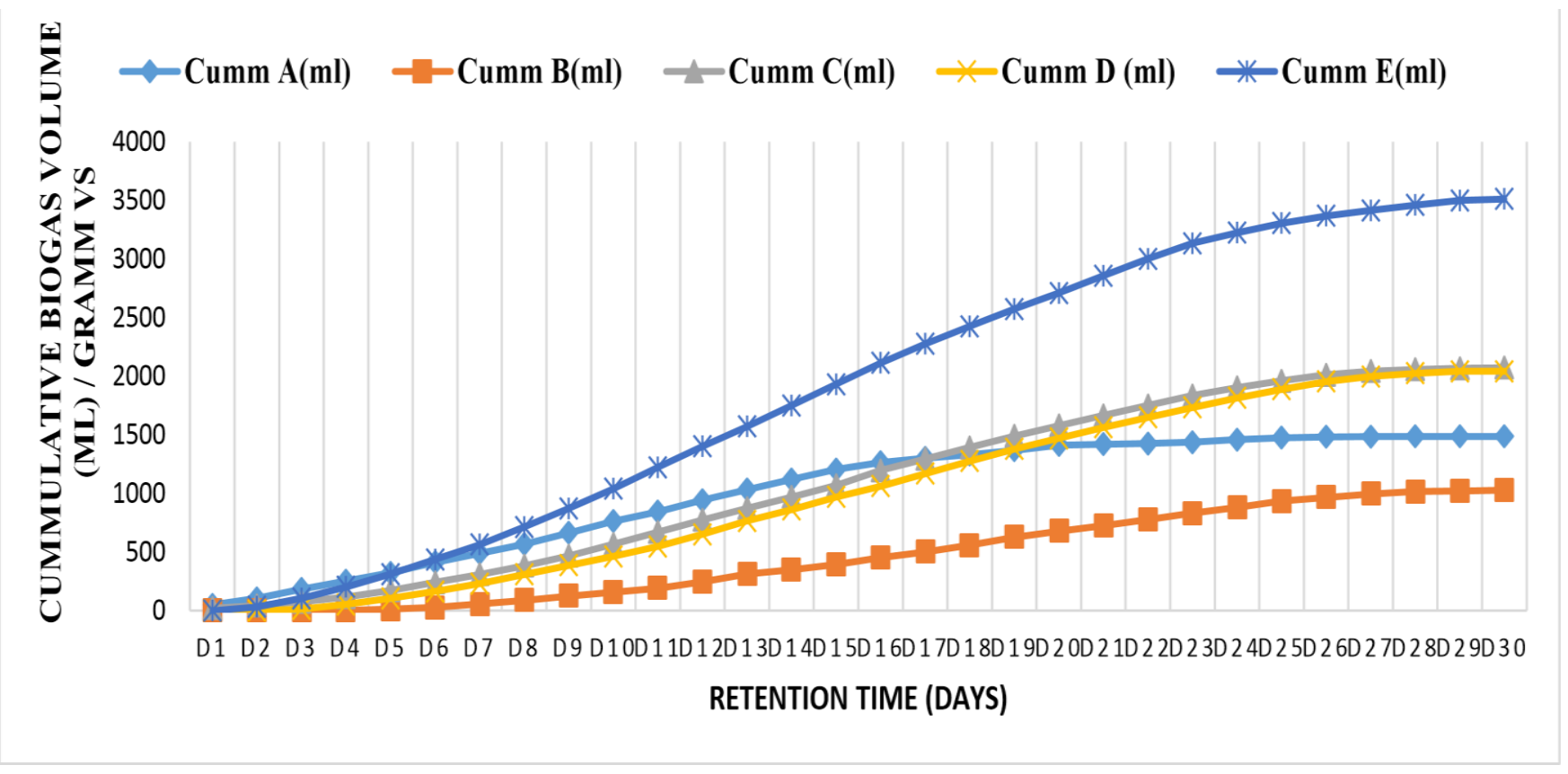

Figure 2: Average cumulative biogas production from slaughterhouse waste

Generally, biogas production was slow at the beginning due to the fact that biogas production rate in batch anaerobic digestion condition directly relies on growth rate of micro-organism in bio-digester. At the beginning, the microorganisms are in the lag phase trying to get used to the new environment. From the $8-12^{\text {th }}$ day, biogas production rate significantly increased due to exponential growth (doubling in numbers) of micro-organisms. Generally, after 12 days, biogas production decreased due to the stationary growth phase of the microorganisms. At the stationary growth phase, the number of microorganisms being produced is equal to the number of microorganisms dieing. The death of the microorganisms was probably due to the accumulation of microbial metabolic wastes which altered the 
environmental conditions necessary for microbial growth and the reduction in food nutrients necessary to support microbial growth.

Treatment E gave the highest biogas production (3512.7 $\mathrm{ml} / \mathrm{g} \mathrm{VS}$ ) (Figure 2). This probably was because of the good mix of the slaughterhouse wastes that improved the $\mathrm{C} / \mathrm{N}$ ratio. Treatment $\mathrm{E}$ contained $10 \%$ cow dung, $70 \%$ punch manure, and $20 \%$ slaughterhouse wastewater. Carbon and Nitrogen serve as good starting structural elements for the bio-synthesis of carbohydrates and proteins that are essential for microbial growth. There was less biogas production (1029.2 $\mathrm{ml} / \mathrm{g}$ VS) from treatment B probably because of too much slaughter wastewater (10\% cow dung and $90 \%$ wastewater). The slaughter wastewater created a hypertonic environment (where by the osmotic potential of the wastewater was higher than that of the microbial cell cytoplasm) that negatively impacted on the growth of microorganisms. From the characterization results, wastewater had the least $\mathrm{C} / \mathrm{N}$ ratio (average of 2.6) hence there was liberation of a lot of nitrogen in form of ammonia in treatment B. During the study period, the temperature fluctuated between 25 and $30^{\circ} \mathrm{C}$ with an average temperature of $28^{\circ} \mathrm{C}$. Methane producing bacteria are temperature sensitive and ideally mesophilic biogas production takes place in a temperature range of 30 to $40^{\circ} \mathrm{C}$ with an optimum temperature of $37^{\circ} \mathrm{C}$. Therefore, the methane production in this study may have been improved if the temperature could have been controlled around $40^{\circ} \mathrm{C}[13]$.

\section{Quality of the biogas from the slaughterhouse wastes}

The methane composition of the biogas produced from the slaughterhouse waste at ambient temperatures ranged from $40.6 \%$ to $50.4 \%$ (Table 4) with treatment $\mathrm{A}$ and $\mathrm{E}$ giving the highest and the least percentages of methane respectively.

Table 4: Average values of the compositions of biogas from the different treatments

\begin{tabular}{lllllll}
\hline Treatments & $\mathbf{C H 4}$ & $\mathbf{C O}_{2}$ & $\mathbf{O}_{2}$ & $\mathbf{N}_{2}$ & $\mathbf{H}_{2} \mathbf{S}$ & $\mathbf{C O}$ \\
$(\boldsymbol{( \% )}$ & $(\boldsymbol{\%})$ & $(\boldsymbol{\%})$ & $(\boldsymbol{\%})$ & $(\mathbf{p p m})$ & $(\mathbf{p p m})$ \\
\hline $\mathrm{A}$ & 50.4 & 28.9 & 0.6 & 0 & 66.5 & 0.8 \\
$\mathrm{~B}$ & 44.7 & 25.1 & 0.4 & 0 & 40.0 & 0.3 \\
$\mathrm{C}$ & 44.1 & 25.3 & 0.5 & 0 & 36.8 & 0.2 \\
$\mathrm{D}$ & 47.3 & 26.6 & 0.4 & 0 & 33.6 & 0.6 \\
$\mathrm{E}$ & 40.6 & 26.2 & 0.5 & 0 & 50.6 & 1.0 \\
\hline
\end{tabular}




\section{Conclusions}

The findings of this study show that there is enough biodegradable waste $(2,597 \mathrm{~L}, 40 \mathrm{~kg}$ and 502 $\mathrm{kg}$ of wastewater, cow dung and punch manure respectively) generated in Lira Municipality slaughterhouse with high potential for biogas production. The quantity and methane content of the biogas from the wastes ranged from 1029.6 to $3512.7 \mathrm{ml} / \mathrm{gVS}$ and 40.6 to $50.4 \%$ respectively. It is therefore possible to generate biogas from biodegradable wastes at ambient temperatures.

\section{List of abbreviations}

LMS: Lira Municipality slaughterhouse, TS: total solids, VS: volatile solids, FS: fixed solids, carbon/nitrogen ratio $(\mathrm{C} / \mathrm{N})$,

\section{Declarations}

\section{Ethics approval and consent to participate}

Not applicable

\section{Consent for publication}

Not applicable

\section{Availability of data and materials}

The data used in this manuscript is available and can be availed by the corresponding author on request.

\section{Competing interests}

There are no competing interests among authors.

\section{Funding}

The funding was done by the researcher themselves with the help of Faculty of Engineering Busitema University.

\section{Authors' contributions}

Isaac Ekwar performed the experiments, Chrish Kavuma and Resty Nabaterega wrote the first manuscript under the guidance of Joseph Lwanyaga and Paul Sserumaga.

\section{Acknowledgments:}

I acknowledge Faculty of Engineering Busitema University for the support rendered to this research.

\section{References:}

[1] M. Vinnari, "The future of meat consumption — Expert views from Finland," vol. 75, pp. 893904, 2008.

[2] N. Technologien and B.- Wirtschaftsberatung, "Anaerobic treatment of slaughterhouse waste and wastewater," vol. 49, no. 0, 2001.

[3] FAO, "Part 3: Feeding the world," FAO Stat. Yearb. 2013, pp. 123-158, 2013. 
[4] H. M. El-Mashad and R. Zhang, "Biogas production from co-digestion of dairy manure and food waste," Bioresour. Technol., vol. 101, no. 11, pp. 4021-4028, 2010.

[5] United Nations Environment Programme, "Developing Integrated Solid Waste Management Plan Training Manual,” UNEP (United Nations Environ. Program. ), vol. Volume 4, pp. 1-176, 2009.

[6] A. M. Zealand, A. P. Roskilly, and D. W. Graham, "Effect of feeding frequency and organic loading rate on biomethane production in the anaerobic digestion of rice straw," Appl. Energy, vol. 207, pp. 156-165, 2017.

[7] P. Sáez-Plaza, T. Michałowski, M. J. Navas, A. G. Asuero, and S. Wybraniec, “An Overview of the Kjeldahl Method of Nitrogen Determination. Part I. Early History, Chemistry of the Procedure, and Titrimetric Finish," Crit. Rev. Anal. Chem., vol. 43, no. 4, pp. 178-223, 2013.

[8] L. L. Kasisira and N. D. Muyiiya, "Assessment of the Effect of Mixing Pig and Cow Dung on Biogas Yield,” CIGR Ejournal, vol. XI, no. 2003, pp. 1-7, 2009.

[9] R. Misganaw, D. F. Habte, and S. Imru, "Digestion of cattle manure and biodegradable kitchen waste to increase biogas production using rumen fluid as inoculums," vol. 2, no. 4, pp. 298-304, 2013.

[10] T. Gebrekidan, M. C. Egigu, and M. Muthuswamy, "Efficiency of biogas production from cactus fruit peel co-digestion with cow dung," Effic. biogas Prod. from cactus fruit peel co-digestion with cow dung, vol. 2, no. 7, pp. 916-923, 2014.

[11] A. K. Jha, J. Li, L. Zhang, Q. Ban, and Y. Jin, "Comparison between Wet and Dry Anaerobic Digestions of Cow Dung under Mesophilic and Thermophilic Conditions," Adv. Water Resour. Prot., vol. 1, no. 2, pp. 28-38, 2013.

[12] S. Riya, K. Suzuki, A. Terada, M. Hosomi, and S. Zhou, "Influence of C/N Ratio on Performance and Microbial Community Structure of Dry-Thermophilic Anaerobic Co-Digestion of Swine Manure and Rice Straw,” J. Med. Bioeng., vol. 5, no. 1, pp. 11-14, 2016.

[13] K. Rajendran, S. Aslanzadeh, and M. J. Taherzadeh, Household biogas digesters-A review, vol. 5, no. 8. 2012. 


\section{Figures}

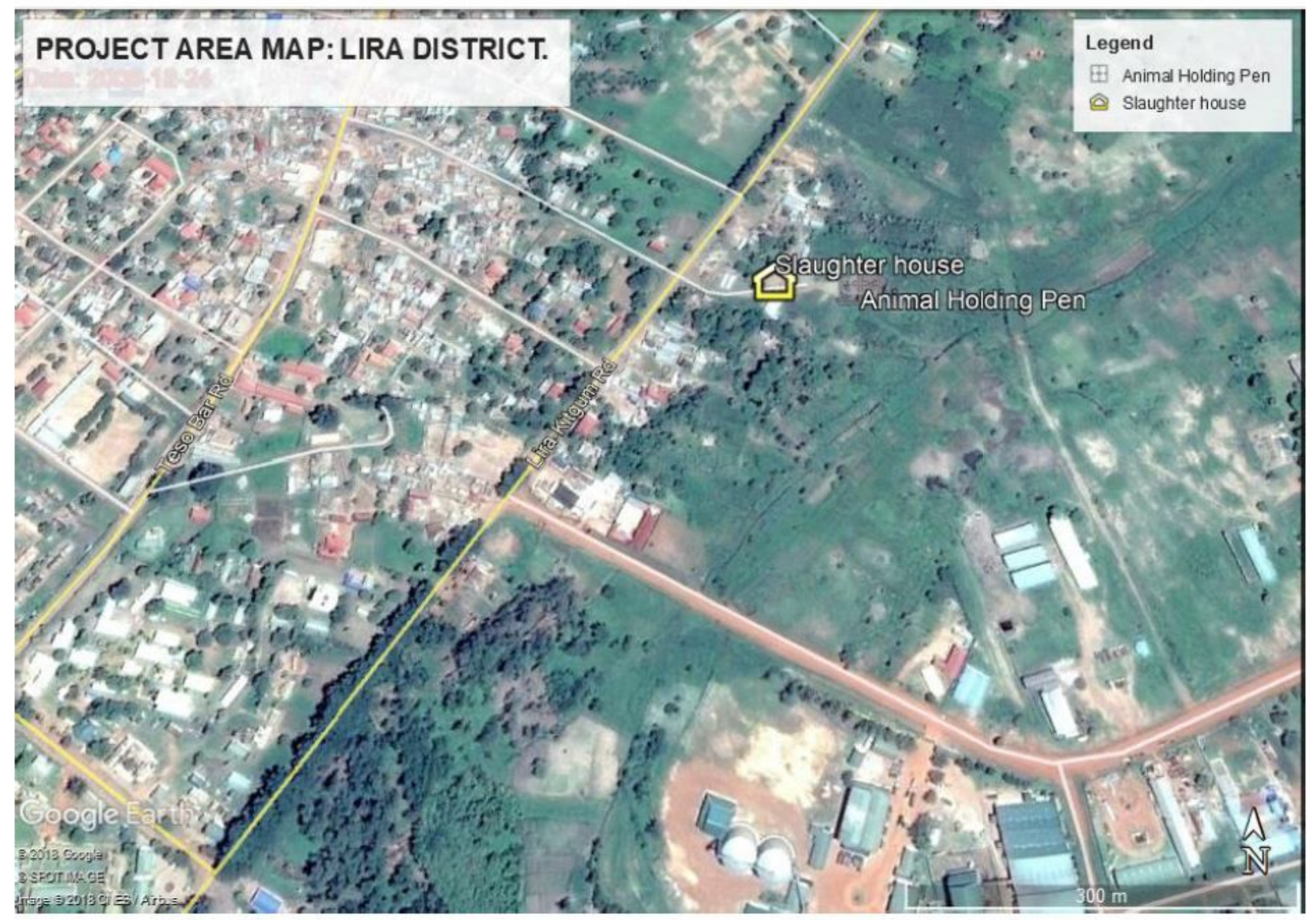

\section{Figure 1}

Map showing Lira slaughter house and Holding pen Note: The designations employed and the presentation of the material on this map do not imply the expression of any opinion whatsoever on the part of Research Square concerning the legal status of any country, territory, city or area or of its authorities, or concerning the delimitation of its frontiers or boundaries. This map has been provided by the authors. 


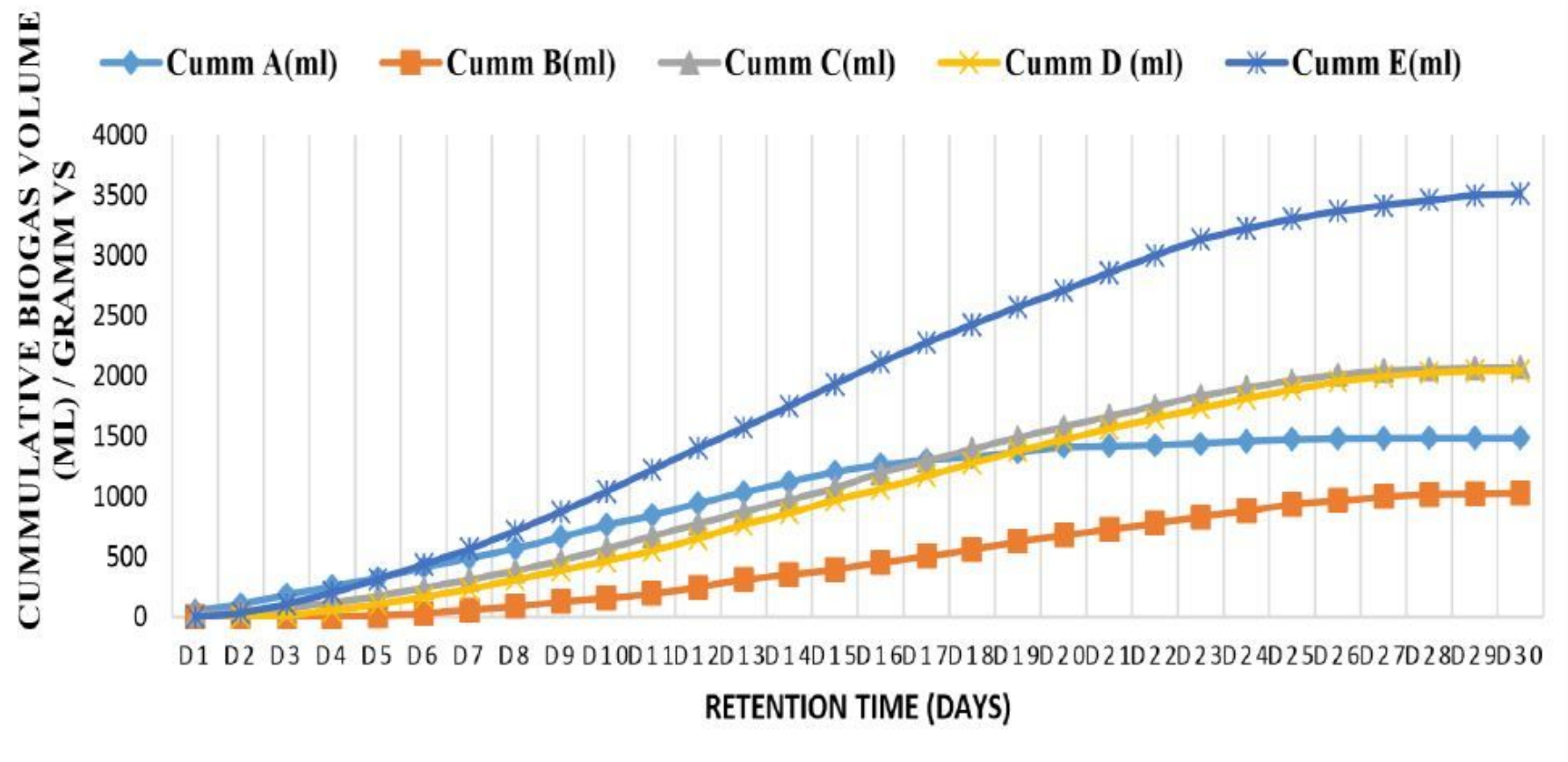

Figure 2

Average cumulative biogas production from slaughterhouse waste 